$\xi=1$ 圆

\title{
Federalism Concepts and Issues in Managing the Malaysian Water Sector
}

\author{
Rasyikah Md Khalid ${ }^{1 *}$ \\ ${ }^{1}$ Faculty of Law, Universiti Kebangsaan Malaysia \\ *Corresponding author E-mail: rasyikah@ukm.edu.my
}

\begin{abstract}
Federalism refers to an agreement between several states which agree to be united as a nation state but with shared administrative responsibility. Under the dual federalism theory, the federal and the state governments are co-equals with specific powers granted by the constitution. In contrast, cooperative federalism denotes that although the federal government is supreme over the states, both acts cooperatively to solve common problem. Malaysia practices dual federalism as legislative powers of the federal and state governments are separated in the Federal Constitution. Rather than fostering cooperation, dual federalism in Malaysia has created tension between different levels of governments in the water sector as highlighted in the Selangor water woes. This paper evaluates issues arising in the Malaysian water sector from the federalism perspectives. Towards this end, doctrinal analysis on relevant laws and commentaries are made to appreciate the meaning of federalism and different approaches towards federalism. The paper concludes that different approaches towards federalstate relation can assist in improving the water sector and solve water conflict between different levels of governments in Malaysia.
\end{abstract}

Keywords: Federalism, Water Sector, Malaysia.

\section{Introduction}

Malaysia is a federation of 13 states and 3 federal territories, with three levels of government- the federal government, the state government and the local government. The federal government which sits at the top of the tier is responsible for matters of national importance such as health, education and finance. The state government however is responsible for matters pertaining to resources, Islamic law, land administration, and forestry. The local government which is the third level is involved with development and licensing of economic activities within its locality.

Interestingly, the administration of water resource is fragmented and shared between the federal, state and local governments. Generally, under a federal system, water administration it is divided into three aspects: (i) planning and development of water infrastructure under the federal government; (ii) water resources management and water supply under the state government; and (iii) land-use planning and control under the local government. Such division is reflected in the constitution of the federation. In 2006, the Federal Constitution of Malaysia was amended to transfer the state's exclusive jurisdiction on water supply sector to the concurrent list. As a result, the federal government established the $\mathrm{Na}$ tional Water Services Commission with the sole executive power on the water supply sector, as opposed to the ideal sharing of responsibility under the concurrent list.

In 2016, the federal government through the Ministry of Natural Resources and Environment has mooted a proposal to enact a national Water Resources Act but emphasized that it will not take away the state government's ownership on water resources. These two efforts clearly illustrate a clear move towards centralization of the water sector in Malaysia. This article analyzes the legitimacy of these centralization exercise from the federalism perspective and its impact on the country's water sector. The analyses are made through content analysis of the laws and documentations pertaining to the federalism issues in Malaysia and other jurisdictions. The article concludes by recommending the application of an appropriate federalism concept to improve the relation between levels of government hence improve the water sector.

\section{Development of the Malaysian Water Sector}

Water has always been regarded as an exclusive 'state' matter as acknowledged by the Reid Commission of 1957 independence when it stated: 'control of inland waters, including all rivers and streams, water supplies and storage is exercised by the States and subject to rights of navigation and to special provisions where the interests of two or more States or the interests of the Municipality of Kuala Lumpur are concerned, we recommend that they should be State subjects'. This does not mean that the federal government has no say in the sector. Article 74 of the Federal Constitution grants powers to the federal government to enact law with respect to matters related to 'water supplies, rivers and canals' and excludes those matter within 'one State or regulated by an agreement between all states concerned; production, distribution and supply of water power'. This provision confines the federal power over water which 'flows through the boundaries of two States or more'. It is also limited to cases of shared rivers where intervention is allowed only when states meet deadlock in their negotiation.

The state governments can legislate on 'water (including rivers and canals but excluding water supplies and services), control of silt, riparian rights' and subject to the Federal List, in light of Article 74 above, and if the water source is wholly within the state's territory'. State jurisdiction over water has been exercised even prior to the drafting of the Federal Constitution with the enactment of Waters Act 1920. The effect of this Act is to grant proprietary 
rights and control of all rivers in the state to the Ruler of the State. Although the federal government is restricted to enact laws on water resources, it has power to legislate for states for the purpose of implementing any treaty or agreement, promoting uniformity or if requested by the state legislature (Article 76 of the Federal Constitution) and it has enacted law or incorporates provisions to govern matters related to water resources in a primary act such as the Irrigation Work Act 1954, Street, Drainage and Building Act 1974 and Environmental Quality Act 1974.

In view of the need to have a more efficient water supply and services, the federal government proposed an amendment to the Federal Constitution to restructure water supply and services sector. In 2005, an amendment was made to the effect that item 'water supply and services' in the state list was transferred to the concurrent list. The Ministry of Energy, Green Technology and Water was established to plan, advice and coordinate all projects related to water resources development, as well as formulate and create policies related to water supply and sewerage services. This enables the federal government to pass the Water Services Industry Act (WSIA) 2006 and the Suruhanjaya Perkhidmatan Air Negara (SPAN) Act 2006. SPAN or the National Water Services Commission employs WSIA as regulatory tools to license, supervise and monitor the industry. Under the National Water Services Industry Restructuring Initiative (NWSIRI), a new federal agency, the Water Asset Management Company or locally known as the Pengurusan Aset Air Berhad (PAAB), will be the nation's water assets owner and manager. It will acquire states' water infrastructure and transform state water operators into asset-light entities and pure service providers. Through NWSIRI, the federal government believe that it will improve the country's water sector.

\section{Federal-State Conflict and Federalism Is- sues in Selangor}

The Selangor's water supply chain is rather complicated. Instead of one water operator and distributor, there are four private concessionaires. They are the Puncak Niaga Sdn. Bhd. (PNSB), the Syarikat Pengeluar Air Sungai Selangor Sdn. Bhd. (SPLASH), the Konsortium Abass Sdn Bhd. (ABASS) and the Syarikat Bekalan Air Selangor Sdn. Bhd. (SYABAS). The first three companies are water treatment operators while SYABAS acts as the single treated water distributor to Selangor as well as the Federal Territory of Kuala Lumpur and Putrajaya. They operate under the Build, Operate, and Transfer (BOT) 30-year concession agreement with the State government.

When the opposition coalition took control of Selangor after the 2008 election, conflict started when the new state government was not happy with the structure of water industry created by the previous state government. The new government, who continues to hold over $70 \%$ interests of all water assets in Selangor, announced that the state government will buy all water assets and control water distribution rights. Upon acquiring the remaining shares, it will transfer the assets to the federal government at a price that will cover the cost of acquisition and compensation for early termination of concessionaires' contracts. The state government has made a series of bids amounted to RM5.709 billion in 2008, RM9.218 billion in 2009 and RM9.277 billion in2010, all rejected by the concessionaires.

Meanwhile, there was also an on-going disagreement abou drought prediction in Selangor. The federal government claimed that there will be water crisis in 2014 and initiated an interstate water transfers from the state of Pahang to Selangor to meet the increasing demand. However, the new Selangor state government claimed that water catchments in Selangor will be able to cater the needs up until 2019 and water shortage will occur if SYABAS fails to keep clean water reserves at good level. Despite the state government's disapproval, the federal government started the controversial Pahang-Selangor Inter-State Raw Water Transfer project on the basis of national importance; but there was a fear that the project will not be completed since the state government has not approved the development of the Langat 2 water treatment plant.

The Selangor water conflict proves that the centralised federalism approach will further jeopardize the relationship between the federal and state government. Fortunately, cooperative federalism crystallized in 2014 when the federal government and the state government of Selangor inked the Memorandum of Understanding (MoU) on 26 February 2014; followed by the Head of Agreements (HoA) on 1 August 2014 to solve their 6-year water conflict. Under the agreement, the state government will allow the development of the Langat 2 water treatment plant, which is the final phase of the Pahang-Selangor raw water transfer project; while the federal government will facilitate the restructuring of the state's water services sector whereby all concessionaires will be managed by the state's owned Air Selangor Sdn Bhd. The ends of the cooperation remain uncertain as political struggle in Selangor continues due to dissatisfaction by some quarters over the cooperation and has led to the dismissal of the Chief Minister of Selangor.

\section{Theories of Federal-State Relationship}

The discussion about federal-state relation in Malaysia as prescribed under Part VI of the Federal Constitution and the Selangor water woes requires further examination on the different concepts of federalism. This is pertinent to understand the different approaches in federal-state relationship and to determine the most workable concept of federalism relevant for the Malaysian water sector. Yusoff argues that in any federation, the constitution becomes an important instrument for dividing powers between two or more levels of government. He quoted Birch [1] who explained that power division will lead 'each [level] in its own sphere, is coordinate with the others, and each acts directly on the people through its own administrative agencies.

Other authors have attempted to enumerate the attributes of federalism as compared to other forms of political organization. Arend Lijphart defines federalism in terms of primary and secondary principles. The primary element of federalism is the guaranteed division of power between central and regional governments and this primary element is supported by five secondary attributes of federalism which are written constitution, bicameral legislature, over-representation of the smaller component unit and their right to be involved in the legislative process, and decentralized government. In contrast to Lijphart, Daniel J. Elazar [2] identifies six ambiguities linked with federalism as a theoretical and operational concept. He argues that federalism can be identified either as a mean to achieve and maintain unity and diversity or as the structure and the process of government. It can also be seen as both a political and cultural phenomenon and can be pursued for both limited and comprehensive ends. It emerges as a mean to accommodate the spreading desire of people to employ common resources while maintaining their cultural distinctiveness within a larger polity.

There are several federalism concepts and countries can apply these concepts strictly or partially. Thus some writers tend to argue that one country conforms to a federal criteria and one does not. Wheare [3] suggested that the United States of America is the best model for the modern idea of federal government and regarded some countries as quasi-federal for subordinating one unit of government to the central government within their constitution. Thus countries like Nigeria, Malaysia and India are to be regarded as quasi-federal since the federal government is permitted to declare a state of emergency on any state and to take over the running of the government of certain region for a specific period of time. In contrast, Elazar noted that there is more than one way to apply federal principles when he said that "federalism can be considered a genus of political organization of which there are several species." He argued that the United States of America invented modern federalism but added a federation as a second form. He 
regarded Europe as confederation when preexisting entities joined to form a common government for specified purposes. He further noted that, as a consequence of the World War II, new federal arrangements have been developed in the form of federacies, associated states arrangements and common market. All these remain part of federal arrangement with slight adjustment made according to the need of each country.

There are arguments that states decide to join a federation due to the benefits that it offers. Inman and Rubinfeld argue that federalism encourages efficient allocation of natural resources, fosters political participation and protects basic liberties and freedom. This will guide them to decide on the characteristic of federalism that they would want based on the number of layers of government, the amount of representation in the federal government and most importantly the amount of authority that each levels of government will get. Although federalism permits diversity, increase political participation and improves efficiency, it can be used to protect certain privileged group. The state and local governments can also frustrate national policy and obstruct actions on national issues. This is not the case in Malaysia as dual and centralized federalism permits the federal government to spread the benefits and costs of government unevenly with lest developed states like Perlis and even lower financial assistance to the state government under the opposition like Kelantan. It is thus vital that Malaysia revisits its concept of federalism in view of the federalism tactics in the American and Australian water sector.

\section{Dual Federalism}

Dual federalism is a concept of federal-state relationship whereby both governments enjoy exclusive and non-overlapping spheres of authority. This is a normal type of federalism as states remain as independent government and not treated as administrative subdivision of the federal government. It has been referred to as the layercake federalism since each level of governments has their own administrative and legislative jurisdiction. In South Carolina v United States (1905) U.S. 437 Justice Brewer described dual federalism as "a dual system of government, national and state, each operating within the same territory and upon the same persons; and yet working without collision, because their functions are different". Thus it ensures each state remains sovereign despite being control to some extent by the federal government and states possess exclusive control over their natural resources and their localities. In most constitutions, distinct division of federal and state legislative powers exhibit clear practice of dual federalism with natural resources remain under the exclusive jurisdiction of the states. In Malaysia, the states of Sabah and Sarawak gain extra powers compared to other states in West Malaysia as a result of agreement to join the Federation of Malaysia. This can be seen in supplements to the State List (List IIA) and the Concurrent List (List IIIA) of the Ninth Schedule of the Federal Constitution of Malaysia where they continue to possess powers over native law and customs, ports and hydroelectricity. The financial provisions however remain centralized with the majority of the income goes to the federal fund. As a whole, the federal government also has more legislative power over states and may legislate on state matters under several circumstances.

In other parts of the world, dual federalism has been practiced in countries like the United States of America, Australia, Canada, Brazil and India. In the United States of America, states have reserved powers that need to be taken into account in determining the extent of powers vested in the federal government. This indicates that states are allowed to perform some of the functions of government free from federal government interference. This position changed in the 1930s when the New Deal policies were introduced to encourage more cooperation between the federal and state governments due to industrialization and globalization. Kincaid [4] argue that as the federal government's role expanded over the century, a shift towards new federalism took place in 1970s to return or devolve some of the power to the state government. This was done mainly on the basis of the subsidiarity principle to give appropriate decision making power to the lowest appropriate level of government. The same progress from dual to cooperative federalism and back to devolution or decentralization can be seen in India whereby the $73^{\text {rd }}$ and $74^{\text {th }}$ amendment to its constitution to create the third tier of government called Panchayati Raj.

The arguments whether dual federalism is still valid or should be discarded has been continuously debated in America, especially true in the context of environmental policy. Engel argues that overlaps between the governments often occurs and static allocation of authority between them contradict the process of federal policymaking in which multiple levels of government interact. Thus, as Engel puts it, the management of environmental ills should be allocated to one or the other level of government with minimal overlap and such allocation "deprives citizens of the benefits of overlapping jurisdiction such as a built-in check upon interest group capture, opportunities for regulatory innovation and refinement, and relief for the courts from the often futile and confusing task of jurisdictional line-drawing."

Although dual federalism is not the exact reflection of most federal system today, critics continue to discourse about relevancy of dual federalism. Schapiro [5] argues that dualist federalism must be inherently local so that it goes beyond the reach of federal power and vice versa. Although dualist federalism accepts some overlap of state and federal authority, it seeks to safeguard some sacred precincts of complete state or federal hegemony, but what is truly 'local' or truly 'national' may not be clearly distinguished and overlaps arises in interstate issues. As Young [6] puts it, the court has to divide the world into two categories like local or national; interstate of intrastate; manufacturing or commerce; in order to "describe distinct fields of regulatory jurisdiction in which one government or the other would have exclusive authority." This confuses the general public and prevents them from exercising self-governance responsibly.

The dualist approach does not also fit in the process of globalization and climate change. As more and more natural resources are being impacted by climate change and as the local industries are becoming more open to threats of globalization, state requires further assistance by the federal government to initiate policies that can ensure a win-win situation to all. In Malaysia, the federal government has been heavily involved in addressing issues like water resources which is mostly local in nature. Although the federal government has the power sharing in water supply and services since 2005 , water that is supplied through the pipe originates from rivers in the state territory and only states should determine whether the amounts of water resources is adequate or to initiates interstate water transfer. The fact that water supply and services is no longer a state's 'exclusive jurisdiction' raises the issue of how jurisdictions need to be shared between the federal and state governments when it falls under the Concurrent List.

\section{Cooperative Federalism}

If dual federalism holds that the federal and state governments are co-equals with specific powers granted by the constitution, cooperative federalism denotes that although federal government is supreme over states, both acts cooperatively to solve common problem. This concept recognizes that overlaps do occur when the federal and state governments are exercising their powers under the constitution. Due to this, Oates [7] argues that the concept has been also referred to as the marble cake federalism to represent the inevitable overlapping duties of the two governments similar to the mixing colors of a marble cake. Schapiro [8] however refers it as interactive federalism which means both parties disregards the boundaries between them and embraces any overlapping through cooperation. Engel [9] coins the concept as dynamic federalism as he believes that "policymakers, courts, and scholars should seek ways to harness and channel the political motivations that lead to 
jurisdictional overlap to minimize its downsides; through legislative solutions that allow states to innovate within the bounds of federal ground rules while providing a flexible framework for interaction between the federal and state players".

Certain elements are needed for cooperative federalism to work. Almost all authors agree that each government possesses certain autonomous powers that may be exercised cooperatively. In Malaysia, the division of the legislative powers between the federal and state governments shows clear intention of dual federalism although cooperation between the two governments is encouraged. Article 76 of the Federal Constitution also provides a basis for cooperation as the federal government can legislate on matters under the State List upon state government's request. In addition, the establishment of a national body such as the National Land Council, the Local Government Council and the Conference of Rulers shows that state's consent remains highly relevant in the national development process.

Despite the dualist approach in legislative power, cooperation can be achieved as the federal principle itself is referred to as "the method of dividing powers so that the general and regional governments are each, within a sphere, coordinate and independent" [3]. Cooperative federalism emerges where both governments are required to work together to achieve a common end. On this Watts [10] explains that the fundamental character of a federal system is a political system characterised by two sub-systems that are neither politically subordinate to each other, but which interact in a cooperatively and competitively manner. In this respect it is submitted that jurisdiction under the Concurrent List under the Federal Constitution indicates cooperative federalism as both government will work together to meet common ends. For this to work, the federal government needs to induce states to cooperate and implement the federal policies at the state level. Sarnoff [11] suggests that one way to induce state cooperation is through the "carrot-and-stick" approach. This mainly refers to cooperation of the state to implement federal policy and they will receive some funding to implement the policies. The fund made available is the 'carrot' and the federal government will impose the 'stick' and take away the fund if state fails to adhere to the federal standards. Fishman [12] argues that the federal 'carrot' will provide a foundation for partnership in cost-sharing for state administration of the federal environmental policy. The 'stick' to the funding refers to continuous federal scrutiny of state programme, enforcement records, issuance of permit and administrative orders. Weiser [13] states that although federal funding seems to be the key for cooperation, the federal government will achieve a certain level of uniformity and compliance when state government comply with the federal government's requirement.

Cooperative federalism has been a practice in Australian water resources management, notably in managing the Murray-Darling river basin which run across the states of New South Wales, Victoria, Queensland and South Australia as well as the Australian Capital Territory. In 1992, the Council of Australian Governments (COAG) was established as a platform for cooperative federalism in Australia [14]. It is an inter-governmental forum in Australia that "initiate, develop and monitor the implementation of policy reforms that are of national significance and which require cooperative action by Australian governments" [15]. In 1994 the council developed the Water Reform Framework to create more efficient water markets through trading in temporary water allocations or permanent water entitlements. This resulted in the implementation of the National Water Initiatives which requires states to develop implementation plan of actions which are of a crossjurisdictional nature. The carrot and stick approach was used when conditional funding was made available by the Commonwealth to induce states to implement the framework by 2010 . By 2008 , the COAG has developed programmes to address urban water reform, enhance water market and improving information flow and capacity building in water resources management.

Cooperative federalism is also entrenched in the Australian Constitution. Section 96 of the Australian Constitution allows the
Commonwealth Parliament to grant financial assistance to any State on such terms and conditions as the Parliament thinks fit. To date, this provision has been interpreted widely to the effect that the Commonwealth has granted funds in areas even beyond its legislative competence. The Commonwealth has in fact used this provision to persuade states to implement federal policy using the carrot and stick approach. Alternatively, the Commonwealth can legislate on water matters by way of states' referral power. Thus it can be seen that prior to the enactment of the Australian Water Act 2007, the Commonwealth's dealing in water resources was done mainly through political deal making with state governments.

In 2007 the Commonwealth uses its power under Section 51(i) (xx) and (xxix) of the Constitution which provides for jurisdiction over trade and commerce, financial corporation and external affairs to pass the Waters Act 2007. The Commonwealth remains optimist that it will continue to receive cooperation from states to manage the Murray-Darling River Basin. Doubts have now arisen over the legality of the Commonwealth's move to use section 51 to legislate on state's matter. However, cooperative federalism remains a workable approach that enables governments at different level to play some role in water resources management in Australia and can be replicated in the inter-state basin in Malaysia.

\section{Other Forms of Federalism and Challenges}

A federal system is theoretically an agreement among states to be governed by another federal government and the system can only work with cooperation between those in the agreement. Problems arise when the federal government assume too much of the legislative power and dual federalism ensues through strict application of the legislative capacity. This becomes more complicated in the management of natural resources as it knows no administrative borders and closely connected to one another in the ecosystem. To some degree, Fischman [12] argues that cooperative federalism is useful in managing natural resources as it enables a more holistic ecological approach towards environmental ills and gave more consideration to the entire ecosystem that depend on a clean environment. However, the dividing line between what is dual or cooperative federalism can sometimes be blurred by the fact that a federal system must involve cooperation between different levels of government in the system.

One notable form of federal-state relationship is known as centralised federalism. Elazar [2] once noted that a federation is 'a polity compounded of strong constituent entities with a strong federal government, each possessing powers delegated to it by the people and empowered to deal directly with the citizenry in the exercise of those powers'. This means that a strong federal is inevitable and the absent of such power may lead to secession or even a collapse of a federation. More often than not a centralized federalism has been intentional. Erk [16] says Finland has moved towards a centralist direction since its inception in 1920 as the federal government took advantage of the weak position of the Austrian provinces (Lander) to the extent that "the Lander has been relegated to the position of administrative subunits in a decentralized state rather than retaining their position as the constituent members of a federal union".

Due to different arrangement of federalism, some authors argue that several federated states do not really exercise the real spirit of federalism. Riker questioned the very existence of federalism by stating that "federalism is no more than a constitutional legal fiction which can be given whatever content seems appropriate at the moment" as he felt that it does not make any difference in the way people are governed. On a similar note, Erk [16] argues that federalism will become relevant if it is developed under the spirit of democracy as it will ensure democratic participation, representation and accountability as well as to accommodate territorially based ethnic, cultural and linguistic differences in divided societies. It will also be relevant for theoretical discourse when it focuses on the implications of federalism for public policy and gov- 
ernmental effectiveness. He however believes that federal system like Austria has moved in a centralist direction when the federal government took advantage of its initial power and expanded into policy areas under the province's jurisdiction. Although the constitution provides Austria as a federation, it works as a unitary state in practice. It can be argued that Malaysia's position is not the same as Austria as the state governments still possess a considerable list of legislative powers. Nevertheless, with more power being assumed by the federal government in the water supply and services sector, it can be seen that the federal government has more say in policy areas whereby state governments should only protect water resources within their territory.

Federal-state relation can also be tested in natural resources management which runs across administrative borders. Some critics refer problems in managing water resources as a "wicked problem" since the solution to these problems is temporary [17], do not react in a scientifically predictable manner [18] and require government to adopt an adaptive approach to the problem [19]. Adaptive federalism has then been introduced as an approach to deal with wicked problems within a federal system; though it is similar to cooperative federalism which requires an implementation plan which is more resilient and adaptive to changes, namely climate change. A fresher look into federalism will acknowledge that it stands better position to adapt to changes than that of a nonfederal system. A federation involves multi-layered governance whereby certain capacity is reserved to a higher level to design policy and allow collective action.

\section{Problems of Centralization and Dual Feder- alism in the Malaysian Water Sector}

The National Water Services Industry Restructuring Initiatives (NWSIRI) can be seen as a move towards centralising the Malaysian water sector. It involves a constitutional amendment which allows the federal government to buy and acquire water infrastructures from the state government and lease them back to water operators; while a federal commissioner, SPAN, will regulate the water operators using a new law called the Water Services Industry Act (WSIA) 2006. However, after a decade, only seven from eleven states in Peninsular Malaysia has migrated to the new regime; Malacca (2008), Negeri Sembilan and Johor (2009), Perlis (2010), Penang (2011), Perak (2012) and Kelantan (2016). Although Selangor has inked some deals totalling RM9.65bil in 2014 , it was not a complete deal since negotiation with another water operator, SPLASH, is still ongoing. With an average of less than one deal per year, the NWSIRI initiated by the federal government is not performing as it hopes for and it is still struggling to secure the deals with Kedah, Terengganu and Pahang. It is also interesting to note that the unsecured deals are with the state governments under the ruling coalition, while state governments under the opposition coalition has inked the agreements. This demonstrate the fact that states are very concerned with the NWSIRI which has taken away their exclusive rights on the water sector.

The 2006 constitutional amendment under the NWSIRI has brought about centralisation of power and de-federalising the country's water sector. It contradicts the spirit of federalism as envisaged by the Reid Commission when it first drafted the constitution. The establishment of SPAN as the new water supply regulator affirms the top down approach of the federal government in the water sector. Effective water governance however should employ a bottom-up approach and those at the lower level should participate in the decision-making process. Centralisation of power through SPAN as a federal agency limits the dynamics that would be created when local communities are actively involved in the management at their river basins. It is noted that the Federation of Malaysian Consumer Association (FOMCA) has a representative in SPAN, but SPAN only focuses on water supply and services. State governments remain responsible for the conservation of water resources at the river basins. The effectiveness and legali- ty of the Water Forum established under WSIA has also been questioned and may defeat its ideal objectives.

It can be seen that the 2005 amendment does not fully solve existing water supply problem, but it has also created a new conflict between the federal and state governments which has not migrated to the new regime. It is important to note that the Federal Constitution provides other avenues for the Federal government to deal with State's matters. Article 76 for instance provides power for Parliament to legislate for states in order to implement international agreement, to promote uniformity of the laws or if requested by the State Legislative Assembly. The 2005 amendment means that States need to share their exclusive power on water with the Federal government. However, since WSIA grants an executive power to SPAN to regulate the sector, it is apparent that the Federal government is taking away their power and imposing a new rule onto the States. Rather than removing States' power under the State List, Article 76 should be employed as a better mechanism to streamline water services sector throughout the country. The National Forestry Act 1984 for instance was introduced by the federal government to promote uniformity in state's forestry laws. Although it is a federal law until state legislature adopts it, it firmly acknowledges states' jurisdiction in forestry. Similar statute can be introduced in the water sector to promote cooperation and avoid conflict that arises from a segregated water sector.

It is interesting to note the drafters of the constitution were never intended that cooperative federalism cannot exist in Malaysia as the Reid Commission [20] explained: "when we say that exclusive responsibility should rest with the Federal Government or with State Government as the case may be we do not intend to hamper or discourage cooperation between the State and the Federation. On the contrary we think that close cooperation between them will promote the interests of all concerned and be of great benefit to the nation". It also felt that it was "unnecessary to make any general reference to such cooperation in the Constitution" except with respect to general power of delegation and the power of the Parliament to legislate on state matters. At the earlier stage, there seemed to be not much of a problem with regard to the cooperation between the federal and most state government as they were ruled by the same coalition party. Nevertheless, lack of such recognition has led the state of Kelantan, which has been governed by the opposition party, to be marginalised in many matters especially in terms of water infrastructure.

\section{Conclusion}

Up until 2017, conflicts between the federal and state government can be avoided if the federal government uphold the spirit of cooperation as envisaged by the Reid Commission. After 60 years of independence, the federal government still assumes central role in the water sector while states merely represent the territorial boundary with many decision or policy making were made at the federal level. Selangor water crisis exemplifies the federal government's uneasiness to the new era of federal-state relationship especially when seeking cooperation and agreement from the state government under Pakatan Rakyat. The crisis also provides the real test of democracy and environmental federalism. The federal government must acknowledge the role played by each state and their local governments in implementing federal environmental policy, especially the water sector.

It is apparent that a good policy and legislative framework can support effective cooperation between the federal and state governments. This can be done either through devolution or decentralisation of power, or merely delegation of relevant executive tasks to the lower government, especially in the climate change mitigation and adaptation program at the local level. The federal government must acknowledge the fact that although climate change is a global problem, the effect of climate change varies by location and different strategies are needed to adapt to climate change, 
especially in river basin management which is closer and more relevant to the local community.

There is also a need to re-define the roles that can be played by different levels of government in the water sector so as to ensure that decision makings are made by the most effective level closest to the water problem. As some state governments have enacted their own water resources authority, they should be in a better position to decide on the planning and development of their water resources project. However, a shift from a strong federal government to governments of equal standing requires more sacrifice from the federal government. Further, constitutional amendment must be avoided if the federal government wants to have greater control in matters under the state jurisdiction. Rather than removing state powers through constitutional amendment, the federal government should employ the 'carrot and stick' approach to ensure both state and local government's cooperation in fulfilling the federal agendas and policies. The creation of more authorities at the federal level will only create further generalization of local problems, sending wrong messages and solutions, and create further animosity between both governments.

\section{Acknowledgement}

The author would like to thank the Ministry of Higher Education and Universiti Kebangsaan Malaysia for funding this research through the grant FRGS/1/2017/SSI10/UKM/02/1. All analysis was made on the relevant water laws and issues up until 2017.

\section{References}

[1] Birch AH (1957), Federalism, Finance and Social Legislation in Canada, Australia and the United States, Clarendon Press, Oxford 306.

[2] Elazar, Exploring Federalism 7.

[3] Wheare KC (1963), Federal Government, Oxford University Press, London, 14.

[4] Kincaid J (1998), 'The Devolution Tortoise and the Centralization Hare', New England Economic Review 15.

[5] Schapiro RA (2007), 'From Dualist Federalism to Interactive Federalism', Emory Law Journal 56(1), 4.

[6] Young EA (2001), 'Dual Federalism, Concurrent Jurisdiction, and the Foreign Affairs Exception', 69 George Washington Law Review, $139-188$

[7] Oates WE (1982), 'The New Federalism: An Economist's View', Cato Journal 475.

[8] Schapiro RA (2007), 'Justice Stevens's Theory of Interactive Federalism', 74 Fordham Law Review, 2133.

[9] Engel KH (2007), 'Harnessing the Benefits of Dynamic Federalism in Environmental Law', 56 Emory Law Journal, 161

[10] Watts R (1970), Administration in Federal System, London: Hutchinson Educational Ltd, 45.

[11] Sarnoff JD (1997), 'The Continuing Imperative (but Only from a National Perspective) for Federal Environmental Protection ', Duke Environmental Law \& Policy Forum, 7(2), 242.

[12] Fischman RL (2006), 'Cooperative Federalism and Natural Resources Law', 14 N.Y. U. Environmental Law Journal 142.

[13] Weiser PJ (2001), 'Towards a Constitutional Architecture for Cooperative Federalism', 79 North Carolina Law Review, 665

[14] Pigram JJ.\&Musgrave WF (1998), Murray-Darling Basin: Cooperative Federalism under Test in Australia. Conflict and Cooperation on Trans-Boundry Water Resources. Just, Kluwer Academic Publishers, 55

[15] Council of Australian Governments, About Council of Australian Governments (2013)

[16] Erk J (2004), 'A Federation without Federalism', Publius 34(1), 1.

[17] Hearnshaw EJS, Tompkins J-M \& Cullen R (2011), Addressing the Wicked Problem of Water Resource Management: An Ecosystem Services Approach. 55th Annual AARES National Conference. Melbourne, Victoria.

[18] Allen, Gerald M, Gould \& Ernest M (1986), Complexity, Wickedness, and Public Forests, Journal of Forestry (84)4, 20-24.

[19] Davidson B \&Malano H (2011),'Wicked Problems Demand Adaptive Responses: How Does the Murray Darling Plan Stack Up?' The
Conversation http://theconversation.com/wicked-problemsdemand-adaptive-responses-how-does-the-murray-darling-planstack-up-4584 (11 January 2014).

[20] Reid Commission, the Federation of Malaya Constitutional Commission, 37. 